\title{
Indonesia Defense Strategy Towards Indo-Pacific (Case Study: The ASEAN Outlook on the Indo-Pacific)
}

\author{
Devindra Oktaviano* Jonni Mahroza Helda Risman \\ Faculty of Defense Strategy, Indonesia Defense University, \\ Indonesia Peace and Security Center - Bogor, Indonesia
}

\begin{abstract}
The emergence of China's economy and military vis-a-vis US's strategy to regain its hegemony has shifted the global political constellation focus to the Southeast Asia region. The recent circumstance in the South China Sea followed by the intensification of the Indo-Pacific strategy, has not only, forcefully put the Southeast Asia region as a theater of China-US geopolitical rivalry, but also increasingly set the complexity of problems to the region. Responding to this context, on June 23, 2019, ASEAN adopted the ASEAN Outlook on Indo-Pacific as foreign policy guidance for its member-states, including Indonesia as an initiator. The objective of this paper is to discuss Indonesia's strategy beyond the ASEAN Outlook. Theoretical framework of regional security complex and regional governance used in explaining the security architecture and political contestation among Southeast Asian countries, and how it influences their stances in ASEAN's role as regional governance within its political mechanism in downplaying Indo-Pacific Strategy. Strategy theory used to analyze how Indonesia develop its strategy to initiate and promote the Outlook beyond its rational interest. Indonesia's role in the initiation and promotion of the ASEAN Outlook is played within the normative framework to upholding persistent regional stability and collective balancing towards the cogency of the Indo-Pacific strategy. Consequently, this condition impels a necessity for Indonesia to build its defense capability without setting aside the free and active policy.

Keywords: Indo-Pacific, Regional Governance, Security Complex, Southeast Asia; Strategy, The ASEAN Outlook
\end{abstract}

DOI: $10.7176 / \mathrm{IAGS} / 80-04$

Publication date: February $29^{\text {th }} 2020$

\section{Introduction}

Terminology of Indo-Pacific as a geopolitical construction emerged from the remarks of Japanese Prime Minister Shinzo Abe in 2007 about the Indian and Pacific as the ocean of freedom and prosperity (Abe, 2007). China and India seaward-oriented foreign policy and United States' vision which can not separate India from its security architecture has driven the US to begin developing its own Indo-Pacific concept (Yoshihara, 2013; Kuo, 2018). In August 2016, the Japanese Prime Minister introduced "Free and Open Indo-Pacific/FOIP" (Kitaoka, 2019). This strategy was quickly accepted and adopted by US. President Trump reasserted US commitment to FOIP in his "Indo-Pacific" visit to five Asian countries on 3-14 November 2017 (The White House, 2017). Thereafter, rather than onomastics, Indo-Pacific developed from a merely maritime space (Khurana, 2007) evolved into a strategic system rising from the rapid and stronger interconnectedness of security and economic issues among regions in the western Pacific and Indian ocean (Medcalf, 2014).

The realization of FOIP contributes to rise another strategic policy namely Quadrilateral Security Dialogue (QUAD), a forum for strategic security dialogue for the United States, Japan, Australia, and India. In the time of ASEAN Summit 2017 in Philippines, the four leaders of the above countries agreed to revive QUAD to promote regional stability and peace. The "QUAD 2.0" forum confirms that there are seven main agendas: law-based order in Asia; freedom of navigation and flight; respect for international law; strengthening connectivity; maritime security; North Korea's threat and nuclear non-proliferation; and terrorism (Rai, 2018). US's traditional strategic ally, Australia, has an Indo-Pacific strategy details which affiliated with FOIP, meanwhile, India's Look East Policy, recently transformed to Act East Policy, has a common orientation with Japan paying serious attention to the strategic value of Southeast Asia and China's maneuvers in the region (Garge, 2017).

Beijing views FOIP as a containment policy against China by the US and allies and also criticizes the emergence of "QUAD 2.0" as "foam in the middle of the ocean" (D. Chen, 2018; Eisentraut and Gaens, 2018). The geopolitical, geoeconomics and geostrategic rivalries have created unconducive political and security instability in the Southeast Asian region. Responding to the circumstances emerged, all ASEAN Member-States came to an understanding during ASEAN Summit 2019 in Thailand by adopting the ASEAN Outlook on the Indo-Pacific. The document is claimed to guide ASEAN member countries in conducting relations and cooperation within the Indo-Pacific region, and in additionally for countries outside the Southeast Asian region when they making interactions with ASEAN countries. Thus, the ASEAN Outlook is trying creating patterns of relations between ASEAN and neighboring countries that contribute to the establishment of peace, freedom, and prosperity (ASEAN Secretariat, 2019b).

The adoption of the ASEAN Outlook on the Indo-Pacific lifted Indonesia in the arena of global politics. 
This Outlook was an Indonesia's initiative submitted to ASEAN since 2018 to build an umbrella for Indo-Pacific cooperation with the concept of ASEAN centrality as delivered by Foreign Minister Retno Marsudi in a speech on January 9, 2019, entitled "Indonesia: Partner for peace, security, prosperity" (Marsudi, 2018). Previously, Indonesia already launched the Global Maritime Fulcrum doctrine to underline its influence and maritime vision towards the strategic position of Southeast Asia.

This paper explains Indonesian Defense Strategy towards the Indo-Pacific strategy within the framework of ASEAN Outlook on the Indo-Pacific. In the next chapter, this article will be divided into three sections: explaining the Southeast Asian regional security complex after the Indo-Pacific conception was present; describes Indonesia's defense interest and policy towards the given regional security architecture and IndoPacific, and then explain the ASEAN Outlook on the Indo-Pacific as an implementation of Indonesia's defense strategy.

\section{Literature Review}

2.1 Regional Security Complex Theory

Barry Buzan and Ole Woever in their book Regions and Powers introduce Regional Security Complex Theory (RSCT) to explain and predict the dynamics of a political region in its position as an international subsystem. A regional security complex is defined as a group of countries where most of the processes of securitization, securitization, or both are interconnected so that the national security problems of each country in the complex cannot be explained apart from each other (Buzan and Woever, 2003).

A regional security complex is categorized within four variables to designate the complexity. First, it is the boundary, which distinguishes it from other security complexes. Second is an anarchic structure which means there are two or more autonomous units / sovereign states in the region. Next is the polarity which indicates the distribution of power between the security complex units. The fourth is social construction, which explains the pattern of amity and enmity among units. Changes to the structure above dynamically will cause a complex security transformation. Internal transformation is occurred in the form of integration-disintegration, ideological competition, and regime change due to changes in the polarity structure, anarchy structure, and social construction. External transformation is occurred when there is a fusion of two or more security complexes or the breaking up of a security complex (Buzan and Woever, 2003).

The RSCT approach is attached importance comprehensively on account of its combining concept of neorealism capability distribution with the concept of securitization (security perceptions) of constructivism and provides an analysis portion to middle and small-power intra-regional countries in explaining the dynamics of security in the region. RSCT is used in a number of working literature which can be seen on an instance in explaining the impact of US and Russian interventions on the stability of the Central Asian region (Troitskiy, 2015); power dynamics and stability in relations between countries in East Asia (Wirth, 2015), or the emergence of a new cold war phenomenon in the Middle East (Hanau Santini, 2017).

\subsection{Concept of Regional Governance}

Governance is understood as a process of regulating social life that can occur at the local, national, regional and global levels (Heywood, 2011). In the $21^{\text {st }}$ century, countries deceived the anarchic international system side by side the multipolar or unipolar world by working together in dealing with all context emerged in the realms of political, economic, social and other issues in the region. Regional governance encompasses state and non-state actors, a set of regulations and procedures both formal and informal, and relations among actors that are competitive or cooperative (Jäger and Köhler, 2008). Different from the more commonly known concept of global governance, regional governance is limited by a group of countries that are geographically close and have similar interests. The well-known practice of regional government is the European Union which facilitates the reterritorialization of various aspects of European policy. In Southeast Asia, ASEAN has survived more than half a century institutionalizing regional political security governance, regional economic governance, and sociocultural governance (Cuyvers, Chen and Lombaerde, 2019).

\subsection{Theory of Strategy}

A strategy is defined as the calculation of objectives, concepts, and resources within acceptable risk limits to create results that are more profitable than results that exist by chance or are in the hands of other parties. (Yarger, 2006). Simply put, a strategy is defined as an act of a subject to calculate behavior based on a particular goal. The state is the main subject in a strategic study related to international relations (Edkins and Zehfuss, 2014). Strategy in the process of formulating and implementing foreign policy means a set of plans and policies consisting of deliberate efforts by the state to utilize political, diplomatic, military and economic instruments together to advance the country's national interests (Feaver, 2009).

Terry Deibel described strategy as a relationship in thought and action between means and ends, resources and objectives, power and purpose, capabilities and intentions in any sphere of human activity (Deibel, 2012, pp. 
3-4). The actor acts rationally in achieving his ends that means political decision-making considerations arise from cost and benefit calculations. The strategic environment at a broader level determines the interests of an actor that causes conflicting interests as each political actor has his own choice and value system. A policymaker formulated a strategy to obtain benefit from the interests of his country while ensuring the other do not benefit from the same interests (Smith, 2011). A strategy that implemented on foreign affairs such us the case of the ASEAN Outlook adoption will build upon six characteristics: coherent, comprehensive, interactive, long-range, means sensitive, and purposeful (Deibel, 2012).

The defense strategy places defense policy as the ends of the national strategy set by a country. The defense strategy can be detailed again in several forms such as general military strategy, defense diplomacy strategy, and management strategy and defense planning. Indonesia described the defense strategy as the integration of military defense and non-military defense in facing various dimensions of threats with the ultimate goal of securing national interests (Kementerian Pertahanan, 2015b)

\section{Methodology}

This paper applies a qualitative methodology in the approach of a case study by developing theories and concepts in the analyzing process based on data collected from books, journals, and other open sources related to the substance discussed.

\section{Result and Discussion}

4.1 Regional Security Complex Parse Southeast Asia

Southeast Asia's security architecture, post-Cold War, can be categorized as a sub-complex within the Asia Super-complex referring to the fact that the region's connections with East and South Asia have become stronger (Buzan, 2003). However, this paper prefers to put Southeast Asia in the analysis as a separate regional security complex within its position and contention facing Indo-Pacific strategy and its trends regionally. Defining regional security complex parse Southeast Asian, Authors elaborate three common variables, i.e., boundary, polarity, and social construction.

Generally, Southeast Asia is politically understood as a group of ASEAN member states. In the 2015 Defense White Book, Indonesia added Timor Leste as one of its partners in the Southeast Asian region (Kementerian Pertahanan, 2015a). The Indo-Pacific Strategy seeks to merge Southeast Asia into a super-regional construction that stretches from East Asia to South Asia. The United States has also integrated a number of policies and strategies in this region. On May $30^{\text {th }}$, 2018, US Secretary of Defense officially renamed US Pacific Command (USPACOM) to US Indo-Pacific Command (USINDOPACOM) on a ceremony in Joint Base Pearl Harbor Hickam (USINDOPACOM, 2018). This change was part of America's defense strategy to strengthen leadership in Indo-Pacific region, engaged India, and countering China's military and economic power projection. A further logic consequence is the relegation influence of ASEAN in defining and determining the direction of policy in the Southeast Asian region.

The polarity of the Southeast Asian regional security complex can be seen as the most affected by the presence of the FOIP in a number of propensities. Several countries show a tendency to be close to China, others maintain strong partnerships with United States, and some strive to remain neutral. Some countries show an increase in the strategic influence of China such as Burma, Cambodia (S. A. Chen, 2018), Laos (Albert, 2019) and the Philippines of the Duterte era (Murphy, 2017). Meanwhile, Singapore is still the main strategic partner of the United States (US Department of State, 2019) and Thailand is also still the key partner of the United States in Southeast Asia (US Department of Defense, 2019).

Good friendship relations have so far been maintained in Southeast Asia when compared to other regions such as the European Union, which is threatened with political and economic vulnerability. The principle of inclusive and non-intervention has a big contribution to minimizing conflict escalation among ASEAN countries. Based on the Treaty of Friendship and Cooperation in Southeast Asia (TAC) signed by the Five ASEAN Founding Countries during the ASEAN Summit in Bali 1976, ASEAN seeks to maintain friendly relations among countries within the region by respecting each other's identity and sovereignty; implementing noninterventions and non-threaten to one another, peaceful dispute resolution, and building effective cooperation (ASEAN Secretariat, 1976). This agreement came to effect to all Member-states in the application of ASEAN principles and norms in various mechanisms and cooperation forums. All major countries had signed the treaty (Cuyvers, Chen and Lombaerde, 2019). After four decades, the TAC continues to find its relevance which in November 2019 Bahrain and Germany also signed the agreement (ASEAN Secretariat, 2019c).

A number of the latest dynamics show tendencies to influence social construction in the Southeast Asian security complex. The threat perception in ASEAN has shifted to the maritime realm. The annual meeting of ASEAN Defense Ministers (ADMM), along with the Non-ASEAN Partners, has become a medium for securitization of maritime issues (Lubis, 2018). This problem is crucial since the center of gravity contestation the Indo-Pacific strategy vis-a-vis BRI China localized in the domain of freedom of maritime navigation and the 
South China Sea issues. In 2016, the ASEAN Summit in Laos failed to produce any agreement due to a dispute over the resolution of the South China Sea dispute (Mogato, Martina and Blanchard, 2016). Maritime issues do have a historical record that divides ASEAN. Something similar has happened to the $21^{\text {st }}$ ASEAN Summit in Cambodia in 2012 (Thul and Stuart Grudgings, 2012).

\subsection{Indonesia's Defense Concerns and Strategy Towards Indo-Pacific}

Indonesia now is confronted with three defense issues in the Southeast Asian region: The South China Sea dispute, the United States strategic policy, and Chinese strategic policy (Kementerian Pertahanan, 2015a). The three of Indonesian archipelagic sea lanes connect the two most strategic maritime areas, the Pacific and Indian Oceans, and the developed countries in southern hemisphere. Indonesia are not claimant states in the South China Sea, but recent incidents indicate that maritime disputes are still a serious concern of Indonesia's defense (Azizah, 2019). Not to mention, the deployment of 2500 US marines to Darwin, Australia, and planning to build a military base on Manus Island, Papua New Guinea, will make Indonesia surrounded by US and allied military bases and affected by regional instability born from the maneuver. These three problems can lead to limited or open wars.

Indonesia's geographical features between two oceans make Indonesia's maritime geopolitical issues crucial. For decades after its independence, Indonesia's geostrategic approach was still limited to unify islands and relations between ASEAN countries. Entering the 21st century, Indonesia expanded its maritime vision range to the Indian and Pacific (Indo-Pacific) oceans. Since then, Indonesia began to face demands to formulate its policy towards the Indo-Pacific trend.

Indonesia views the Indo-Pacific as a prospective region because it has a lot of potentials that can be exploited and cooperated with. As a consequence, Indonesia considers it necessary to maintain the stability of the security of the area and ensure that the two maritime regions do not become a battleground for territories and natural resource struggles and reject the claims of maritime supremacy (Marsudi, 2019). Indonesia's struggle to implement its national interests in the Indo-Pacific must face the United States, China, Australia, India, and Japan, which also have policies on the region. Indonesia's diplomacy towards China is characterized by two trends: competing in geopolitics and cooperating in geoeconomics. Before Japan and the United States translated the region's strategic value into FOIP in the past two years, several countries have offered various approaches to the Indo-Pacific, including Indonesia itself.

Since 1946, Indonesia has a foreign policy principle called the Free and Active Policy. In the defense context, this principle is implemented in the form of rejecting the defense alliance (Kementerian Pertahanan, 2015a). The Indonesian constitution mandates regional and global stability as one of the cores of national interests. Therefore, Indonesia's defense strategy is directed to eliminates turbulences in the Southeast Asia region by put cooperation forward with any countries regardless of political sides

The formulation of Indonesia's foreign policy towards the Indo-Pacific region was developed gradually starting from the Indo-Pacific Treaty of Friendship and Cooperation (IPTFC), the Maritime Axis that connects the Indian Ocean and Pacific Ocean, and the Indo-Pacific Cooperation Concept (IPCC). In 2013, Indonesia began to adopt the Indo-Pacific concept in line with the popularity of the term in the international geopolitical arena. The foreign ministry translated the concept as a crossing of two ocean regions with Indonesia placed in a central position (Scott, 2019).

Indonesia sees the strategy of the Belt and Road Initiative of China, the Free and Open Indo-Pacific of Japan and the United States, and the East India Act undermined the ASEAN primacy on governing the high developing economic and great demography quantity of Southeast Asia region. The entire strategy above covers the strategic waters of the world in which Indonesia also has sovereignty over some of these waters. To accommodate these interests, Indonesia actively holds maritime diplomacy based on independent and proactive principles, development orientation, and rule-based approach (Kemenko Kemaritiman, 2019).

The defense strategy that is commonly applied by countries in the Southeast Asian region when confronted with the rivalry of great power is Hedging Strategy. This type of strategy seeks resistance or creates contradictory actions as a way to minimize or mitigate weaknesses risk related to the behavior of alliances. Key indicators of the Hedging strategy include strengthening the military without declaring hostility, increasing participation in bilateral and multilateral cooperation, the absence of decisive balancing and bandwagoning efforts and strengthening of simultaneous relations with two regional powers (Murphy, 2017).

Indonesia also adopted the same strategy when faced with the current regional and global security architecture. The strategy developed by Indonesia's defense diplomacy must take into account Indonesian foreign policy factors that adhere to the principle of free and active, limited defense capability, geostrategic position, and uncertain dynamics in the regional and global strategic security environment. Defense strategy within the framework of Indonesia's hedging strategy is a way to achieve three main agendas, namely: building mutual trust (confidence building), strengthening defense capability, and the development of the local defense industry (Gindarsah, 2016). 
Another characteristic of Indonesia's hedging strategy is the centrality of ASEAN. Indonesia's international relations are mainly oriented towards interactions within the ASEAN framework. The fact that Indonesia is the largest country, the largest population, and one of the founding countries of ASEAN makes Indonesia always positioned as a natural leader in the organization. The principle of ASEAN centrality can be understood as one of Indonesia's ways to gather strength to form a collective balancing of large forces outside the region that can change the regional security architecture. Although ASEAN is unable to work further to maintain the security architecture due to the principle of non-intervention, ASEAN remains an instrument of diplomacy and Indonesia's foreign policy in Asia. ASEAN provides a strategic space while addressing the capability gap between the countries of Southeast Asia and large countries outside the region (Gindarsah, 2016).

\subsection{The ASEAN Outlook as an Implementation of Indonesia's Strategy}

Various steps have actually been taken by Indonesia to face the Indo-Pacific strategy. In 2018, Indonesia introduced the Indo-Pacific Cooperation Concept which substantially reinforces the earlier Indo-Pacific Treaty of Friendship and Cooperation. The different values offered from this concept are ASEAN-based centrality approaches. Two major geopolitical upheavals in Southeast Asia namely the South China Sea dispute and intervention by China and the United States in intrastate and interstate ASEAN affairs have prompted Indonesia to build bilateral and multilateral negotiations with some ASEAN countries. Collective solutions are assumed by Indonesia will be able to minimize the intensity of threats to Indonesia's foreign policy vision of the Indo-Pacific region. However, a number of obstacles are still faced considering that ASEAN countries have not yet accepted the concept proposal, the scope of cooperation is still targeting ordinary security issues, and the unclear orientation of Indonesia's behavior to Great Power (Scott, 2019).

Indonesia is again striving for its vision of the Indo-Pacific by circulating the Indo-Pacific insight proposal in May 2018 by carrying out three points: creating an international system based on international law and peaceful resolution of conflicts; following up on transnational issues in the region and creating an open and equitable economic system in the Pacific and Indian oceans (Choong, 2019). In an open forum, the Indo-Pacific concept of Indonesia was then presented before the ASEAN countries at the 8th East Asian Summit on November 8, 2018, and claimed to receive positive appreciation. A year later, Indonesia's proposal was successfully accepted and adopted by ASEAN as the ASEAN Outlook which is contained in the $56^{\text {th }}$ point of 57 points agreed on the results of the 34th ASEAN Summit in Bangkok (ASEAN Secretariat, 2019b). The results of the summit also called for intervention by parties outside Southeast Asia in the region should be carried out in a collaborative approach in certain fields that have been described in the ASEAN Outlook document.

The Outlook stands on the principle of ASEAN centrality, inclusive, complementary, non-intervention, and international law-based order. Rather than directing the Indo-Pacific into a security and military approach, the Outlook encourages countries outside the region to partner with countries in Southeast Asia in the areas of economy, maritime, environment and disaster management, connectivity, and achievement of the 2030 UN SDG. ASEAN emphasizes the mechanism of dialogue and cooperation as a model of involvement of actors outside the region (ASEAN Secretariat, 2019a).

The ASEAN Outlook institutes Indonesia's vision of the Indo-Pacific which is considered as the most inclusive compared to Japanese, Australian, Indian and of course the United States version (Gyngell, 2019). For Indonesia, ASEAN is not a place to confuse these variations of vision, but rather to find common ground so that mutual trust arises (Pramono, 2018). Indonesia rejects the realism-style approach that puts forward the concept of threat in international relations but instead chooses to hold all parties to become partners in cooperation.

The preferences of the ASEAN Outlook cooperation sector very well represent the interests of Indonesia's foreign policy. Starting the second period of his reign, President Joko Widodo instructed that the economy be a central issue of future state diplomacy (Asmara, 2019). Indonesia in the last five years ago also introduced the doctrine of the Global Maritime Fulcrum which promotes policies to build maritime power in the Indian and Pacific oceans (Muhibat, 2017). The concept is the same as previous which exploited Indonesia's geographical superiority but this one is emphasized in the maritime sector.

The Global Maritime Fulcrum is comprehensive as it giving birth to new concepts such as maritime security, maritime diplomacy, maritime economics, and maritime power (Scott, 2019). To conduct these complex inseparable objectives, Indonesia's maritime affairs ministry and defense ministry, as well as foreign affairs ministry, have to work together and raise cooperations both at regional and international levels (Hidayat and Ridwan, 2017). The ASEAN Outlook is precisely answering this issue at the parallel time persuasively preventing Indonesia from the escalation of threats that come from geopolitical rivalry.

ASEAN defines the Indo-Pacific as a combination of the Asia-Pacific region and the Indian Ocean region that are interconnected and integrated, not as a single contiguous territorial unit. ASEAN emphasized that it would build cooperation in the Indo-Pacific region, but for the Southeast Asia region, ASEAN remained as a central actor in determining the security and economic architecture. Penetration of actors outside the region which may change the architecture of the region in Southeast Asia will be responded by approaches and 
mechanisms directed by ASEAN. Thus, the ASEAN Outlook is not a way for Indonesia to change or create new regional architecture. The East Asia Summit (EAS) became one of the recommended forums for consultation dialogue offered by the ASEAN Outlook for the scale of ASEAN and the region (ASEAN Secretariat, 2019a). The Outlook rejects the military and security approaches that are widely socialized by the United States in order to shape the ideals of peace, stability, prosperity in the region.

Table 1: Comparing US-lead Indo-Pacific Strategy vs ASEAN's Indo-Pacific approach

\begin{tabular}{|l|l|l|}
\hline Aspects & INDO-PACIFIC STRATEGY & $\begin{array}{l}\text { THE ASEAN OUTLOOK ON THE INDO- } \\
\text { PACIFIC }\end{array}$ \\
\hline Region Border & $\begin{array}{l}\text { Indo-Pacific as contiguous territorial } \\
\text { space }\end{array}$ & $\begin{array}{l}\text { Indo-Pacific as an interconnected Asia-Pacific and } \\
\text { Indian Ocean Region }\end{array}$ \\
\hline Main Principle & Free and Open & Inclusive, Openness, ASEAN Centrality \\
\hline $\begin{array}{l}\text { Interaction } \\
\text { model }\end{array}$ & $\begin{array}{l}\text { Bilateral/minilateral cooperation; } \\
\text { strategic alliance }\end{array}$ & Multilateral cooperation; dialog and consultation \\
\hline $\begin{array}{l}\text { Cooperation } \\
\text { focus }\end{array}$ & Security and Defense & $\begin{array}{l}\text { Economy, Maritime, Connectivity, Human } \\
\text { Development }\end{array}$ \\
\hline
\end{tabular}

In the defense sector, ASEAN already has a multilateral ASEAN Defense Ministerial Meeting (ADMM) forum that discusses and elaborates defense issues and policies among ASEAN countries and regional partners. The skepticism about the effectiveness of ASEAN in governing defense interests can be denied by the presence of ADMM as a practical multilateralism (Tan, 2018). Even though defense issue is not in the recommendation cooperation sector, the ADMM offers a multilateral approach with details of the program based on local issues of the Southeast Asian region and without the tendency of strategic alliances which makes it very relevant to be applied within the framework of the ASEAN Outlook on the Indo-Pacific. Indonesia's defense strategy through ADMM is aimed at building confidence that will shift the pattern of enmity relations to amity and become an instrument for introducing Indonesian defense equipment and conveying interest and vision of Indonesia's defense in the region (Lubis, 2018; Rusfiana, 2018).

Indonesia's active maneuver to pass the ASEAN Outlook on the Indo-Pacific is seen as Indonesia's defensive stance to defend its security and political interests in the Asia Pacific region. Indonesia is utilizing its central influence in ASEAN to foster collaboration among small countries in Southeast Asia. The final product of this collaboration is to increase Indonesia's relative power to balance the power of the United States in Southeast Asia. Indonesia took the initiative to create a system that has mechanisms and norms to fight US aggressiveness. Using ASEAN as an instrument is Indonesia's rational move because Indonesia will get enough power to maintain the security posture of the Southeast Asian region. Although the ASEAN Outlook is neither an agreement nor binding (Acharya, 2019) the successful adoption of the following document reflects progress in achieving Indonesia's defense strategy agenda towards Southeast Asia's regional security architecture.

\section{Conclusion}

The Indo-Pacific Strategy is part of the big agenda of rebalancing policy in Asia rolled out by the United States. The existence of the Indo-Pacific slowly changes the architecture of the security complex of the Southeast Asian region which will create a strategic space that benefits the US and its allies. The potential transformation of the security complex impacts all countries in the region, including Indonesia.

Indonesia in the past decade has implemented a hedging strategy to deal with the changing trends in the regional and global strategic security environment. Challenges arise from the penetration of strategies and visions of great powers outside the region that can change the security architecture of the Southeast Asian region. However, Indonesia needs a stable region to support the achievement of national goals.

The long-initiated Indo-Pacific strategy began to show very significant developments in 2017 which were also accompanied by the revival of the QUAD strategic security dialogue. The motivation to counteract the strategy of BRI China has resulted in intense geopolitical feuds in the Southeast Asian region, which is currently the belle of the international political constellation.

The ASEAN Outlook on the Indo-Pacific is Indonesia's defense strategy to maintain the architecture of the security complex of the Southeast Asian region. The outputs of the principles, mechanisms, and orientations emphasized by the Outlook minimize or slow down the transformation of the security complex which will impact destabilization. Indonesia's vital position in ASEAN is utilized by submitting the Outlook proposal and then successfully adopted by ASEAN.

The ASEAN Outlook was proposed in such a way as to maximize the centrality of ASEAN without rejecting the involvement of actors outside the region. The fusion of Southeast Asia's geopolitical construction into a large region stretching from the western Pacific to the Indian Ocean will diminish Indonesia's influence, given that Indonesia's existence in international relations depends on its active maneuver in ASEAN. The interaction model offered in the form of cooperation and dialogue will lead to social construction in a region dominated by friendly relations rather than hostilities. 


\section{References}

Abe, S. (2007) 'Confluence of Two Seas' Speech by Prime Minister of Japan at the Parliament of Republic of India, Ministry of Foreign Affairs of Japan. Tokyo. Available at: https://www.mofa.go.jp/region/asiapaci/pmv0708/speech-2.html (Accessed: 5 January 2020).

Acharya, A. (2019) Why ASEAN's Indo-Pacific outlook matters | East Asia Forum, East Asia Forum. Available at: https:/www.eastasiaforum.org/2019/08/11/why-aseans-indo-pacific-outlook-matters/ (Accessed: 28 December 2019).

Albert, E. (2019) China Digs Deep in Landlocked Laos, The Diplomat. Available at: https://thediplomat.com/2019/04/china-digs-deep-in-landlocked-laos/ (Accessed: 30 December 2019).

ASEAN Secretariat (1976) Treaty of Amity and Cooperation in Southeast Asia. Available at: https://asean.org/treaty-amity-cooperation-southeast-asia-indonesia-24-february-1976/ (Accessed: 2 January 2020).

ASEAN Secretariat (2019a) "ASEAN Outlook on the Indo-Pacific". Jakarta. Available at: https://asean.org/storage/2019/06/ASEAN-Outlook-on-the-Indo-Pacific_FINAL_22062019.pdf.

ASEAN Secretariat (2019b) Chair's Statement of the 34th ASEAN Summit Bangkok, 23 June 2019 Advancing Partnership For Sustainability. Jakarta. Available at: https://asean.org/storage/2019/06/Final ChairsStatement-of-the-34th-ASEAN-Summit_as-of-23-June-2019-12....pdf (Accessed: 28 December 2019).

ASEAN Secretariat (2019c) Signing Ceremony of the Instrument of Accession to the Treaty of Amity and Cooperation (TAC), ASEAN Thailand 2019. Available at: https://www.asean2019.go.th/en/news/signingceremony-of-the-instrument-of-accession-to-the-treaty-of-amity-and-cooperation-tac/ (Accessed: 2 January 2020).

Asmara, C. G. (2019) Jokowi ke Menlu Retno: Perkuat Diplomasi Ekonomi, Consumer News and Business Channel Indonesia. Available at: https://www.cnbcindonesia.com/news/20191023132819-4109406/jokowi-ke-menlu-retno-perkuat-diplomasi-ekonomi (Accessed: 3 January 2020).

Azizah, K. (2019) Alasan Kapal-Kapal China Masuk Perairan Indonesia Hingga Berujung Klaim Kedaulatan, Merdeka.com. Available at: https:/www.merdeka.com/trending/alasan-kapal-kapal-china-masuk-perairanindonesia-hingga-berujung-klaim-kedaulatan.html (Accessed: 10 January 2020).

Buzan, B. (2003) 'Security architecture in Asia: The interplay of regional and global levels', Pacific Review, 16(2), pp. 143-173. doi: 10.1080/0951274032000069660.

Buzan, B. and Woever, O. (2003) Regions and Powers: The Structure of International Security. Cambridge: Cambridge University Press.

Chen, D. (2018) What China Thinks of the Indo-Pacific Strategy, The Diplomat. Available at: https://thediplomat.com/2018/05/what-china-thinks-of-the-indo-pacific-strategy/ (Accessed: 6 January 2020).

Chen, S. A. (2018) 'The Development of Cambodia-China Relation and Its Transition Under the OBOR Initiative', Chinese Economy. Routledge, 51(4), pp. 370-382. doi: 10.1080/10971475.2018.1457317.

Choong, W. (2019) 'The return of the Indo-Pacific strategy: an assessment', Australian Journal of International Affairs. Taylor \& Francis, 0(0), pp. 1-16. doi: 10.1080/10357718.2019.1639134.

Cuyvers, L., Chen, L. and Lombaerde, P. De (2019) '50 years of regional integration in ASEAN', Asia Pacific Business Review. Routledge, 25(5), pp. 609-618. doi: 10.1080/13602381.2019.1652975.

Deibel, T. L. (2012) Foreign affairs strategy: Logic for American statecraft, Foreign Affairs Strategy: Logic for American Statecraft. Cambridge: Cambridge University Press. doi: 10.1017/CBO9780511806773.

Edkins, J. and Zehfuss, M. (2014) Global Politics: A New Introduction. 2nd edn. London: Routledge.

Eisentraut, S. and Gaens, B. (2018) The US-Japan-India-Australia Quadrilateral Security Dialogue: IndoPacific alignment or foam in the ocean?, FIIA BRIEFING PAPER. 239. Helsinki. Available at: https://www.fiia.fi/sv/publikation/the-us-japan-india-australia-quadrilateral-security-dialogue?read (Accessed: 6 January 2020).

Feaver, P. (2009) What is grand strategy and why do we need it?, Foreign Policy. Available at: https://foreignpolicy.com/2009/04/08/what-is-grand-strategy-and-why-do-we-need-it/（Accessed: 17 January 2020).

Garge, R. (2017) 'Maritime outreach as part of India's “Act East” policy', Australian Journal of Maritime and Ocean Affairs. Taylor \& Francis, pp. 1-18. doi: 10.1080/18366503.2017.1285217.

Gindarsah, I. (2016) 'Strategic hedging in Indonesia's defense diplomacy', Defense and Security Analysis. Taylor \& Francis, 32(4), pp. 336-353. doi: 10.1080/14751798.2016.1233695.

Gyngell, A. (2019) To each their own 'Indo-Pacific', East Asia Forum. Available at: https://www.eastasiaforum.org/2018/05/23/to-each-their-own-indo-pacific/ (Accessed: 29 December 2019).

Hanau Santini, R. (2017) 'A New Regional Cold War in the Middle East and North Africa: Regional Security Complex Theory Revisited', International Spectator. Routledge, 52(4), pp. 93-111. doi: 10.1080/03932729.2017.1371487. 
Heywood, A. (2011) Global Politics. New York: Palgrave Macmillan.

Hidayat, S. and Ridwan (2017) 'Kebijakan Poros Maritim dan Keamanan Nasional Indonesia: Tantangan dan Harapan', Jurnal Pertahanan \& Bela Negara, 7(3), pp. 107-121.

Jäger, J. and Köhler, B. (2008) Theoretical Approaches to Regional Governance: Theory of Governance. Available at: www.fh-vie.ac.at results.

Kemenko Kemaritiman (2019) Buku Putih Diplomasi Maritim Indonesia. Jakarta.

Kementerian Pertahanan (2015a) Buku Putih Pertahanan. Jakarta.

Kementerian Pertahanan (2015b) Buku Strategi Pertahanan Negara 2015. Jakarta.

Khurana, G. S. (2007) 'Security of sea lines: Prospects for india-japan cooperation', Strategic Analysis, 31(1), pp. 139-153. doi: 10.1080/09700160701355485.

Kitaoka, S. (2019) 'Vision for a Free and Open Indo-Pacific', Asia-Pacific Review. Taylor \& Francis, 26(1), pp. 7-17. doi: 10.1080/13439006.2019.1618592.

Kuo, M. (2018) The Origin of 'Indo-Pacific' as Geopolitical Construct - The Diplomat, The Diplomat. Available at: https://thediplomat.com/2018/01/the-origin-of-indo-pacific-as-geopolitical-construct/ (Accessed: 28 December 2019).

Lubis, R. R. (2018) 'Sekuritisasi Isu Keamanan Maritim Dalam Mendukung Diplomasi Pertahanan Indonesia di ADMM Plus On Maritime Security', Jurnal Pertahanan \& Bela Negara, 8(1), pp. 27-44. doi: 10.33172/jpbh.v8i1.264.

Marsudi, R. (2018) Indonesia: Partner for peace, security, prosperity, The Jakarta Post. Available at: https://www.thejakartapost.com/academia/2018/01/11/indonesia-partner-for-peace-security-prosperity.html (Accessed: 29 December 2019).

Marsudi, R. (2019) Pernyataan Pers Tahunan Menteri Luar Negeri Republik Indonesia Retno L.P. Marsudi Tahun 2019, Kementerian Luar Negeri. Available at: kemlu.go.id/portal/id/read/55/pidato/pernyataan-perstahunan-menteri-luar-negeri-ri-tahun-2019 (Accessed: 5 January 2020).

Medcalf, R. (2014) 'In defence of the Indo-Pacific: Australia's new strategic map', Australian Journal of International Affairs, 68(4), pp. 470-483. doi: 10.1080/10357718.2014.911814.

Mogato, M., Martina, M. and Blanchard, B. (2016) ASEAN deadlocked on South China Sea, Cambodia blocks statement, Reuters. Available at: https:/www.reuters.com/article/us-southchinasea-ruling-asean/aseandeadlocked-on-south-china-sea-cambodia-blocks-statement-idUSKCN1050F6 (Accessed: 2 January 2020).

Muhibat, S. F. (2017) 'Indonesia's New Ocean Policy: Analysing the External Dimension', Maritime Affairs: Journal of the National Maritime Foundation of India. Taylor \& Francis, 13(2), pp. 50-61. doi: 10.1080/09733159.2017.1410936.

Murphy, A. M. (2017) 'Great power rivalries, domestic politics and Southeast Asian foreign policy: Exploring the linkages', Asian Security. Routledge, 13(3), pp. 165-182. doi: 10.1080/14799855.2017.1354566.

Pramono, S. (2018, Dec 19). Interview by Diana Dwika. Indonesia Forward [Television broadcast]. Jakarta: Cable News Network Indonesia.

Rai, A. (2018) 'Quadrilateral Security Dialogue 2 (Quad 2.0)-a credible strategic construct or mere "foam in the ocean”?', Maritime Affairs. Taylor \& Francis, 14(2), pp. 138-148. doi: 10.1080/09733159.2019.1572260.

Rusfiana, Y. (2018) 'Diplomasi Pertahanan Indonesia Dalam Asean Defence Ministerial Meeting (Admm)', Jurnal Pertahanan \& Bela Negara, 4(2), pp. 145-164. doi: 10.33172/jpbh.v4i2.335.

Scott, D. (2019) 'Indonesia Grapples with the Indo-Pacific: Outreach, Strategic Discourse, and Diplomacy', Journal of Current Southeast Asian Affairs, 38(2), pp. 194-217. doi: 10.1177/1868103419860669.

Smith, M. L. R. (2011) Strategic Theory: What it is... and just as importantly, what it isn't, E-International Relations. Available at: https://www.e-ir.info/2011/04/28/strategic-theory-what-it-is...and-just-asimportantly-what-it-isn't/ (Accessed: 22 January 2020).

Tan, S. S. (2018) 'From ARF to ADMM+: Is the Asia-Pacific Finally Getting Multilateralism Right', Asian Studies Review. Routledge, pp. 1-16. doi: 10.1080/10357823.2019.1691502.

The White House (2017) Statement from the Press Secretary on President Donald J. Trump's Upcoming Travel to Asia. Available at: https://www.whitehouse.gov/briefings-statements/statement-press-secretary-presidentdonald-j-trumps-upcoming-travel-asia/ (Accessed: 30 December 2019).

Thul, P. C. and Stuart Grudgings (2012) SE Asia meeting in disarray over sea dispute with China, Reuters. Available at: https://www.reuters.com/article/us-asean-summit/se-asia-meeting-in-disarray-over-seadispute-with-china-idUSBRE86C0BD20120713 (Accessed: 2 January 2019).

Troitskiy, E. F. (2015) 'Central Asian regional security complex: The impact of Russian and us policies', Global Society, 29(1), pp. 2-22. doi: 10.1080/13600826.2014.961125.

US Department of Defense (2019) Indo-Pacific Strategy Report: Preparedness, Partnerships, and Promoting a Networked Region. Available at: https://media.defense.gov/2019/Jul/01/2002152311/-1/1/1/DEPARTMENT-OF-DEFENSE-INDO-PACIFIC-STRATEGY-REPORT-2019.PDF.

US Department of State (2019) A Free and Open Indo-Pacific: Advancing a Shared Vision. Available at: 
https://www.state.gov/a-free-and-open-indo-pacific-advancing-a-shared-vision/.

USINDOPACOM (2018) U.S. Indo-Pacific Command Holds Change of Command Ceremony, US Indo-Pacific Command. Available at: https:/www.pacom.mil/Media/News/News-Article-View/Article/1535776/usindo-pacific-command-holds-change-of-command-ceremony/ (Accessed: 23 January 2020).

Wirth, C. (2015) "'Power" and "stability" in the China-Japan-South Korea regional security complex', Pacific Review, 28(4), pp. 553-575. doi: 10.1080/09512748.2015.1012538.

Yarger, H. R. (2006) Strategic Theory for the 21st Century: the Little Book On Big Strategy, Strategic Studies Institute.

Yoshihara, T. (2013) 'The US Navy's Indo-Pacific challenge', Journal of the Indian Ocean Region, 9(1), pp. 90-103. doi: 10.1080/19480881.2013.793914. 